\title{
Reduced Kidney Function and Relative Hypocalciuria-Observational, Cross-Sectional, Population-Based Data
}

\author{
Massimo Cirillo ${ }^{1, *(\mathbb{D})}$, Giancarlo Bilancio ${ }^{2}{ }^{(\mathbb{D}}$, Pierpaolo Cavallo ${ }^{3,4} \mathbb{D}$, \\ Francesco Giordano $^{2}$, Gennaro Iesce ${ }^{2}$, Simona Costanzo ${ }^{5}$ (D), Amalia De Curtis ${ }^{5}$, \\ Augusto Di Castelnuovo ${ }^{6}$ and Licia Iacoviello ${ }^{5,7}$ (D) \\ 1 Department of Public Health, University of Naples Federico II, 80131 Naples (NA), Italy \\ 2 Department Scuola Medica Salernitana, University of Salerno, 84081 Baronissi (SA), Italy; \\ giancarlo.bilancio@gmail.com (G.B.); francesco.giordano1989@gmail.com (F.G.); \\ iesceg@gmail.com (G.I.) \\ 3 Department of Physics, University of Salerno, 84084 Fisciano (SA), Italy; pcavallo@unisa.it \\ 4 Istituto Sistemi Complessi, Centro Nazionale Ricerche, 00185 Rome (RM), Italy \\ 5 Department of Epidemiology and Prevention, IRCCS Neuromed, 86077 Pozzilli (IS), Italy; \\ simona.costanzo@neuromed.it (S.C.); amalia.decurtis@moli-sani.org (A.D.C.); \\ licia.iacoviello@uninsubria.it (L.I.) \\ 6 Mediterranea Cardiocentro, 80122 Napoli (NA), Italy; dicastel@ngi.it \\ 7 Department of Medicine and Surgery, Research Center in Epidemiology and Preventive Medicine (EPIMED), \\ University of Insubria, 21100 Varese (VA), Italy \\ * Correspondence: massimo.cirillo@unina.it; Tel.: +39-081-7461-111
}

Received: 2 November 2020; Accepted: 18 December 2020; Published: 21 December 2020

\begin{abstract}
This observational, cross-sectional, epidemiological analysis investigated relationships of kidney function to urine calcium and other variables. The analyses targeted two population-based samples of adults (Gubbio study and Moli-sani study: $n=3508$ and 955, respectively). Kidney function was assessed as estimated glomerular filtration rate (eGFR). Calcium/creatinine ratio $(\mathrm{Ca} / \mathrm{Cr})$ was used as index of urinary calcium in timed overnight urine under fed condition (Gubbio study), morning urine after overnight fast (Gubbio study), and first-void morning urine (Moli-sani study). Moli-sani study included also data for glomerular filtered calcium load, tubular calcium handling, and serum phosphorus, parathyroid hormone, 1,25-dihydroxyvitamin D, calcium, and 25-hydroxyvitamin D. eGFR positively and independently related to $\mathrm{Ca} / \mathrm{Cr}(p<0.001)$. In multivariate analyses, eGFR lower by $10 \mathrm{~mL} / \mathrm{min} \times 1.73 \mathrm{~m}^{2}$ related to overnight urine $\mathrm{Ca} / \mathrm{Cr}$ lower by $14.0 \mathrm{mg} / \mathrm{g}$ in men and $17.8 \mathrm{mg} / \mathrm{g}$ in women, to morning urine $\mathrm{Ca} / \mathrm{Cr}$ lower by $9.3 \mathrm{mg} / \mathrm{g}$ in men and $11.2 \mathrm{mg} / \mathrm{g}$ in women, and to first-void urine $\mathrm{Ca} / \mathrm{Cr}$ lower by $7.7 \mathrm{mg} / \mathrm{g}$ in men and $9.6 \mathrm{mg} / \mathrm{g}$ in women $(p<0.001)$. eGFR independently related to glomerular filtered calcium load $(p<0.001)$ and did not relate to tubular calcium handling $(p \geq 0.35)$. In reduced eGFR only $\left(<90 \mathrm{~mL} / \mathrm{min} \times 1.73 \mathrm{~m}^{2}\right)$, low urine $\mathrm{Ca} / \mathrm{Cr}$ independently related to low serum 1,25-dihydroxyvitamin $\mathrm{D}(p=0.002)$ and did not relate to hyperphosphatemia, high serum parathyroid hormone, or hypocalcemia $(p \geq 0.14)$. Population-based data indicated consistent associations of lower kidney function with lower urine calcium due to reduction in glomerular filtered calcium. In reduced kidney function, relative hypocalciuria associated with higher prevalence of low serum 1,25-dihydroxyvitamin D.
\end{abstract}

Keywords: kidney function; eGFR; calcium; parathyroid hormone; 1,25-dihydroxyvitamin D; epidemiology 


\section{Introduction}

The term 'chronic kidney disease-mineral and bone disorder' (CKD-MBD) is used to define a complex syndrome secondary to the chronic decline in kidney function that encompasses the progressive appearance of biochemical, skeletal, and cardiovascular abnormalities [1]. The CKD-MBD biochemical abnormalities include the reduction of 1,25-dihydroxyvitamin $\mathrm{D}\left[1,25(\mathrm{OH})_{2} \mathrm{D}\right]$, the increase in serum phosphorus and serum parathyroid hormone (PTH), and the possible reduction in serum calcium (Ca) [1]. The current guidelines recommend the monitoring of the serum lab tests for early diagnosis and control of CKD-MBD [1]. The guidelines do not mention urine tests although, at least theoretically, low serum concentrations of $1,25(\mathrm{OH}){ }_{2} \mathrm{D}$ together with high serum concentrations of PTH could contribute to secondarily reduced urine Ca [2]. Two studies reported data regarding the relationship between kidney function and urine Ca [3,4]. In 2007, Craver et al. reported a positive, non-linear relationship of kidney function with $24 \mathrm{~h}$ urinary $\mathrm{Ca}$ in a subgroup of 319 nephropathic patients with glomerular filtration ranging from $<15$ to $\geq 90 \mathrm{~mL} / \mathrm{min} \times 1.73 \mathrm{~m}^{2}$ as assessed by creatinine clearance predicted using the Cockcroft-Gault formula [3]. In 2019, Ramalho et al. reported a positive, linear relationship of kidney function with $24 \mathrm{~h}$ urinary $\mathrm{Ca}$ in 365 patients with estimated glomerular filtration rate (eGFR) ranging from $\geq 15$ to $59 \mathrm{~mL} / \mathrm{min} \times 1.73 \mathrm{~m}^{2}$ [4]. Two other studies retrospectively investigated urinary Ca and kidney function in kidney stone(s) patients [5,6], hence in patients in whom the high prevalence of hypercalciuria could play a major confounding [7]. Data on the association between kidney function and urinary $\mathrm{Ca}$ are missing in the general population. Data are missing also for urine collected under fasting conditions to assess the possible role of the intake or absorption of $\mathrm{Ca}$ [8]. The present study analyzed two sets of epidemiological data to investigate the relationship of kidney function with urinary $\mathrm{Ca}$ in general population. It also reports the consistence of results under fed and fasting conditions, and in different population samples, the relationship of kidney function with classical indices of kidney Ca handling, and the possible use of urine $\mathrm{Ca}$ as proxy of biochemical abnormalities typical of CKD-MBD.

\section{Methods}

The Gubbio study is a population-based cohort study ongoing since 1982 in the city of Gubbio, Italy [9]. The study adheres to the Declaration of Helsinki of 1975, as revised in 2013, and included an informed consent and the approval by the institutional committee (CEAS-Umbria \#2850/16). Study design, main exams, response rates, and characteristics of the Gubbio cohort were previously reported [9]. The present analysis deals with data collected at the second exam of the study (1989-92) [9]. The exam included the following: timed collection of overnight urine under fed conditions from the first void after the completion of the evening dinner to the first void at morning wake-up included [10]; early morning blood sample collected after an overnight fast and after the completion of the overnight urine collection [9-11]; morning urine collection under fasting conditions performed after blood sampling [11]; medical visit for measurements of anthropometry and blood pressure and for administration of questionnaires [9]. Urine concentrations of $\mathrm{Ca}$ and creatinine were measured in fresh samples using automated biochemistry and quality controls [9]. Serum creatinine was measured in frozen samples by automated biochemistry (Express Plus, Bayer Diagnostic) using a kinetic alkaline picrate assay with IDMS-traceable standardization [12]. Variability in blind duplicates was $<5 \%$ for all these measurements [9]. Target cohort for the present analysis consisted of 4670 examinees who, at the second exam of the Gubbio study, were aged $\geq 18$ years and with complete data for eGFR and overnight urine. Of these examinees, 1162 were excluded because of missing morning urine collection under fasting conditions. Thus, the Gubbio study dataset included 3508 adults with complete data both for overnight urine and for morning urine under fasting conditions. Excluded examinees had similar overnight urine $\mathrm{Ca} /$ creatinine ratio and slightly lower values for female sex prevalence, age, body mass index, and eGFR (Table S1).

The Moli-sani study is a prospective cohort study ongoing since 2005 that enrolled 24,325 individuals from 2005 to 2010, men and women, aged $\geq 35$ years, randomly recruited from the general 
population of a region of central-southern Italy [13]. The study complies with the Declaration of Helsinki of 1975, as revised in 2013, and was approved by the Rome Catholic University ethical committee (P99, A.931/03-138-04, 11 February 2004). All participants provided written informed consent. The baseline visit included questionnaires about socioeconomic status, physical activity, medical history, dietary habits, risk factors, personal and family medical history; measurements of blood pressure and anthropometry; collection of untimed urine spot samples from the first void at wake up; collection of morning venous blood samples after an overnight fast. Biological samples were processed for lab tests within $3 \mathrm{~h}$ and/or stored in liquid nitrogen as described [14]. Lab tests for the whole cohort included the measurements of serum cystatin C [15]. Target cohort for the present analysis was a sub-group of 1000 examinees of the Moli-sani study that were selected by a sex- and age- stratified randomization for additional lab tests using frozen samples of serum and urine [16]. The stratification was designed to have 100 men and 100 women for each one of the following five age-groups: $35-44,45-54,55-64,65-74$, and $\geq 75$ years. Additional lab tests included the measurements of the urine concentrations of creatinine, $\mathrm{Ca}$, and phosphorus, and the measurements of serum concentrations of creatinine, total $\mathrm{Ca}$, albumin, phosphorus, total 25-hydroxy-vitamin $\mathrm{D}$ [25(OH)D], PTH, and 1,25(OH) ${ }_{2} \mathrm{D}$ [16]. Automated biochemistry was used for the measurements of serum creatinine, $\mathrm{Ca}$, albumin, phosphorus, $\mathrm{PTH}$ and for the measurements of urine creatinine, and Ca (Abbott, IL, USA) [16,17]. Serum creatinine was measured by enzymatic assay calibrated with IDMS-traceable standard [12]. The measurements of $25(\mathrm{OH}) \mathrm{D}$ and $1,25(\mathrm{OH})_{2} \mathrm{D}$ were performed by a fully automated chemiluminescent assay (Diasorin, Saluggia, Italy) $[16,18]$. As previously described and in accordance with guidelines [16,19], the 25(OH)D assay was calibrated using ID-LC-MSand ID-LC-MS/MS- traceable standard NIST-SRM 972a [20]. Intra- and inter- assay variability of chemiluminescent methods in blind duplicates was $<5 \%$ [16]. The date of visit that was used to calculate the average local solar global horizontal irradiance in the month prior to blood withdrawal (from here on defined as solar irradiance) [21]. This variable was used to control the analyses for the possible effect of ultraviolet exposure on serum 25(OH)D [22]. Of the subgroup selected for additional lab test, 45 examinees were excluded because of missing data. Thus, the Moli-sani study dataset included 955 adults with complete data for urine and serum.

\subsection{Measurements in the Gubbio Study Dataset}

Kidney function was assessed as eGFR calculated by the Chronic Kidney Disease-Epidemiology Collaboration equation with the use of serum creatinine, ethnicity, sex, and age [23]. Both in overnight and in morning fasting urine, urine $\mathrm{Ca}$ was assessed as urine $\mathrm{Ca} /$ creatinine ratio [24] to exclude the errors in timing and completeness inevitable in timed collections [25]. Previous papers showed that overnight urine Ca excretion rate highly correlated with 24-h urinary Ca [26,27]. Figure S1 in Supplementary Material shows the correlation between overnight $\mathrm{Ca} /$ creatinine ratio and the estimated ratio for $24 \mathrm{~h}$ urine. The list of variables in analyses included also anthropometry, estimated $24 \mathrm{~h}$ urinary creatinine [28], ending time of evening meal, duration of overnight fast from completion of the evening meal to initiation of morning fasting urine collection, reported habitual intake of milk or yogurt [29] as index of the major dietary source of absorbable Ca [30], and reported treatment with Ca or vitamin D supplementation.

\subsection{Measurements in the Moli-Sani Study Dataset}

Kidney function was assessed as eGFR calculated by the Chronic Kidney Disease-Epidemiology Collaboration equation including serum creatinine, ethnicity, sex, age, and cystatin $C$ also to reduce the confounding of creatinine generation [31,32]. Urine $\mathrm{Ca}$ was assessed as urine $\mathrm{Ca} /$ creatinine ratio similarly to the Gubbio dataset. For the investigation of kidney Ca handling, the following indices were calculated: serum albumin-bound $\mathrm{Ca}=$ serum albumin as $\mathrm{g} / 100 \mathrm{~mL}$ times the multiplier 0.88 [33]; serum ultra-filterable $\mathrm{Ca}=$ serum total $\mathrm{Ca}$ minus serum albumin-bound $\mathrm{Ca}$; glomerular filtered $\mathrm{Ca}$ load $=$ serum ultra-filterable $\mathrm{Ca}$ times eGFR; fractional Ca excretion $=$ urine $\mathrm{Ca} /$ serum ultra-filterable 
Ca times serum creatinine/urine creatinine [34]; fractional tubular Ca reabsorption $=1-$ fractional Ca excretion [34]. For investigation on metabolic abnormalities of CKD-MBD [1], hypocalcemia was defined as serum total $\mathrm{Ca}<8.6 \mathrm{mg} / 100 \mathrm{~mL}$, hyperphosphatemia as serum $p \geq 4.5 \mathrm{mg} / 100 \mathrm{~mL}$, high serum $\mathrm{PTH}$ as serum PTH $\geq 66 \mathrm{pg} / \mathrm{mL}$, and low serum $1,25(\mathrm{OH})_{2} \mathrm{D}$ as $1,25(\mathrm{OH})_{2} \mathrm{D}<18 \mathrm{pg} / \mathrm{mL}$ [35].

\subsection{Statistical Analyses}

eGFR was the main independent variable in both datasets and was divided in the following seven strata: $\geq 90,89-75,74-60,59-45,44-30,29-15$, and $<15 \mathrm{~mL} / \mathrm{min} \times 1.73 \mathrm{~m}^{2}$. eGFR $<90 \mathrm{~mL} / \mathrm{min}$ $\times 1.73 \mathrm{~m}^{2}$ was defined as reduced kidney function [36]. First, the relationship of eGFR to urinary $\mathrm{Ca}$ was investigated by univariate ANOVA of $\mathrm{Ca}$ /creatinine ratio along eGFR strata for overnight urine (Gubbio study dataset), morning fasting urine (Gubbio study dataset), and first-void morning urine (Moli-sani study dataset). The independence of results from urine creatinine was investigated by multi-variable ANOVA and linear regression with control for age and weight that, together with sex, are the main predictors of creatinine generation [28]. As ancillary data, the Supplementary Material includes additional analyses in the Gubbio study dataset for overnight urine calcium excretion rate, estimated $24 \mathrm{~h}$ urinary Ca calculated as overnight urine $\mathrm{Ca} /$ creatinine times $24 \mathrm{~h}$ urinary creatinine, and $\mathrm{Ca} /$ creatinine ratio in overnight urine of the 1162 examinees excluded from analyses due to missing morning urine collection under fasting conditions. After that, in the Moli-sani dataset, the relationships of eGFR to indices of kidney Ca handling and to metabolic indices of CKD-MBD were investigated using univariate and multi-variable ANOVA along eGFR strata. Finally, analyses in the Moli-sani dataset investigated the association of urine $\mathrm{Ca} /$ creatinine ratio with the prevalence of CKD-MBD metabolic abnormalities separately in the group without reduced kidney function and in the group with reduced kidney function. To this aim, chi-square analysis, ANOVA, and logistic regression were performed along the following four strata of urine $\mathrm{Ca} /$ creatinine ratio: $\geq 100,99-75$, $74-50$, and $<50 \mathrm{mg} / \mathrm{g}$. All analyses were done separately in men and women. Statistical procedures were performed using IBM-SPSS 19. Results were reported as prevalence for categorical variables, mean \pm SD for numerical non-skewed variables, median with interquartile range (IQR) for numerical skewed variables, regression coefficient, odds ratio (OR), and 95\% confidence interval $(95 \% \mathrm{CI})$.

\section{Results}

\subsection{Descriptive Statistics}

Table 1 shows descriptive statistics by sex in the two datasets. Mean age was approximately 10-year higher in the dataset of the Moli-sani study that did not enroll individuals with age 18-34 years but only individuals with age $\geq 35$ years. In both datasets, men and women differed for anthropometry, urine and serum creatinine, eGFR, urine $\mathrm{Ca}$, urine creatinine, and $\mathrm{Ca} /$ creatinine ratio. In the Gubbio study dataset, $\mathrm{Ca}$ /creatinine ratio was higher in overnight urine than morning urine after overnight fast. In both datasets, no examinee had eGFR $<15 \mathrm{~mL} / \mathrm{min} \times 1.73 \mathrm{~m}^{2}$. In both datasets, there were positive trends along eGFR strata for female sex prevalence, age, and body mass index (Tables S2 and S3).

Table 1. Descriptive statistics in the Gubbio study dataset and the Moli-sani study dataset: prevalence, mean \pm SD for numerical non-skewed variable, and median (IQR) for numerical skewed variables ^.

\begin{tabular}{lcccc}
\hline & \multicolumn{2}{c}{ Gubbio Study } & \multicolumn{2}{c}{ Moli-Sani Study } \\
\hline & Men & Women & Men & Women \\
\hline Number of examinees & 1555 & 1953 & 488 & 467 \\
\hline Demographics and anthropometry & & & & \\
\hline Age, years & $49.4 \pm 16.8$ & $51.0 \pm 16.7$ & $59.7 \pm 9.6$ & $59.9 \pm 10.1$ \\
\hline Weight, $\mathrm{kg}$ & $77.0 \pm 11.4$ & $64.8 \pm 11.3$ & $80.8 \pm 13.2$ & $69.2 \pm 13.3$ \\
\hline Body mass index, $\mathrm{kg} / \mathrm{m}^{2}$ & $26.9 \pm 3.7$ & $26.6 \pm 4.8$ & $28.6 \pm 4.2$ & $28.7 \pm 5.5$ \\
\hline
\end{tabular}


Table 1. Cont.

\begin{tabular}{|c|c|c|c|c|}
\hline & \multicolumn{2}{|c|}{ Gubbio Study } & \multicolumn{2}{|c|}{ Moli-Sani Study } \\
\hline & Men & Women & Men & Women \\
\hline \multicolumn{5}{|l|}{ Kidney function } \\
\hline Serum creatinine, $\mathrm{mg} / 100 \mathrm{~mL}$ & $0.96(0.89 / 1.03)$ & $\begin{array}{c}0.83 \\
(0.77 / 0.89)\end{array}$ & $\begin{array}{c}0.88 \\
(0.80 / 0.97)\end{array}$ & $\begin{array}{c}0.72 \\
(0.66 / 0.80)\end{array}$ \\
\hline Serum cystatin $\mathrm{C}, \mathrm{mg} / \mathrm{L}$ & n.a. & n.a. & $0.99(0.88 / 1.13)$ & $0.98(0.87 / 1.10)$ \\
\hline eGFR, $\mathrm{mL} / \mathrm{min} \times 1.73 \mathrm{~m}^{2}$ & $92.2 \pm 15.7$ & $83.4 \pm 16.5$ & $84.6 \pm 15.6$ & $81.5 \pm 16.4$ \\
\hline$\%$ eGFR $89-60 \mathrm{~mL} / \mathrm{min} \times 1.73 \mathrm{~m}^{2}$ & $39.5 \%$ & $58.8 \%$ & $52.4 \%$ & $60.4 \%$ \\
\hline$\%$ eGFR $<60 \mathrm{~mL} / \mathrm{min} \times 1.73 \mathrm{~m}^{2}$ & $2.3 \%$ & $6.5 \%$ & $7.5 \%$ & $9.8 \%$ \\
\hline \multicolumn{5}{|l|}{ Urinary variables } \\
\hline Estimated urinary creatinine, $\mathrm{g} / 24 \mathrm{~h}$ & $1.54 \pm 0.18$ & $1.00 \pm 0.16$ & $1.52 \pm 0.18$ & $1.00 \pm 0.17$ \\
\hline Overnight urine $\mathrm{Ca}, \mathrm{mg} / \mathrm{L}$ & $129(92 / 182)$ & $\begin{array}{c}121 \\
(82 / 172)\end{array}$ & n.a. & n.a. \\
\hline Overnight urine creatinine, $\mathrm{g} / \mathrm{L}$ & $1.44(1.01 / 1.98)$ & $\begin{array}{c}100 \\
(67 / 150)\end{array}$ & n.a. & n.a. \\
\hline Overnight urine $\mathrm{Ca} /$ creatinine ratio, $\mathrm{mg} / \mathrm{g}$ & $108 \pm 68$ & $139 \pm 82$ & n.a. & n.a. \\
\hline Morning fasting urine $\mathrm{Ca}, \mathrm{mg} / \mathrm{L}^{\wedge}$ & $110(76 / 147)$ & $\begin{array}{c}102 \\
(69 / 136) \\
\end{array}$ & n.a. & n.a. \\
\hline Morning fasting urine creatinine, $\mathrm{g} / \mathrm{L}^{\wedge}$ & $1.61(1.14 / 2.14)$ & $\begin{array}{c}118 \\
(77 / 166)\end{array}$ & n.a. & n.a. \\
\hline Morning fasting urine $\mathrm{Ca} /$ creatinine ratio, $\mathrm{mg} / \mathrm{g}$ ^ & $79 \pm 48$ & $100 \pm 57$ & n.a. & n.a. \\
\hline First-void morning urine $\mathrm{Ca}, \mathrm{mg} / \mathrm{L}^{\wedge}$ & n.a. & n.a. & $\begin{array}{c}42 \\
(21 / 81) \\
\end{array}$ & $\begin{array}{c}31 \\
(15 / 59) \\
\end{array}$ \\
\hline First-void morning urine creatinine, $\mathrm{g} / \mathrm{L}^{\wedge}$ & n.a. & n.a. & $0.68(0.32 / 1.13)$ & $0.31(0.17 / 0.65)$ \\
\hline First-void morning urine $\mathrm{Ca} / \mathrm{creatinine}$ ratio, $\mathrm{mg} / \mathrm{g}$ ^ & n.a. & n.a. & $92 \pm 60$ & $126 \pm 68$ \\
\hline \multicolumn{5}{|l|}{ Kidney Ca handling } \\
\hline Glomerular filtered Ca load, $\mathrm{mg} / \mathrm{min}$ & n.a. & n.a. & $467 \pm 85$ & $446 \pm 87$ \\
\hline Tubular fractional Ca reabsorption, $\%$ & n.a. & n.a. & $98.8(98.1 / 99.2)$ & $98.5(97.8 / 99.0)$ \\
\hline Fractional Ca excretion, $\%$ & n.a. & n.a. & $1.21(0.80 / 1.90)$ & $1.51(0.98 / 2.20)$ \\
\hline \multicolumn{5}{|l|}{ CKD-MBD metabolic markers } \\
\hline Serum phosphorus, $\mathrm{mg} / 100 \mathrm{~mL}$ & n.a. & n.a. & $2.94 \pm 0.56$ & $3.34 \pm 0.61$ \\
\hline Serum PTH, pg/mL & n.a. & n.a. & $23.5(17.9 / 30.4)$ & $23.0(17.1 / 29.5)$ \\
\hline Serum $1,25(\mathrm{OH})_{2} \mathrm{D}, \mathrm{pg} / \mathrm{mL}$ & n.a. & n.a. & $38.4 \pm 11.6$ & $37.5 \pm 10.9$ \\
\hline Serum $25(\mathrm{OH}) \mathrm{D}, \mathrm{ng} / \mathrm{mL}$ & n.a. & n.a. & $22.2 \pm 11.9$ & $21.1 \pm 12.8$ \\
\hline Serum total Ca, mg/100 mL & n.a. & n.a. & $9.35 \pm 0.30$ & $9.27 \pm 0.30$ \\
\hline Serum albumin, $\mathrm{g} / \mathrm{L}$ & n.a. & n.a. & $43.5 \pm 2.6$ & $43.1 \pm 2.5$ \\
\hline Serum ultra-filterable Ca, mg/100 mL & n.a. & n.a. & $5.52 \pm 0.16$ & $5.48 \pm 0.18$ \\
\hline \multicolumn{5}{|l|}{ Other variables } \\
\hline$\%$ with Ca supplementation & $0.8 \%$ & $0.9 \%$ & $0.6 \%$ & $1.7 \%$ \\
\hline$\%$ with vitamin D supplementation & $0.6 \%$ & $1.2 \%$ & $0.4 \%$ & $4.9 \%$ \\
\hline Habitual intake of milk or yogurt, mL/day & $\begin{array}{c}12 \\
(0 / 125) \\
\end{array}$ & $\begin{array}{c}63 \\
(0 / 125)\end{array}$ & n.a. & n.a. \\
\hline Ending time of evening meal, hour:min & $\begin{array}{c}20: 30 \\
(20: 00 / 21: 00)\end{array}$ & $\begin{array}{c}20: 50 \\
(20: 00 / 21: 00) \\
\end{array}$ & n.a. & n.a. \\
\hline Duration of the overnight urine collection, $\mathrm{h}$ & $8.2 \pm 1.1$ & $8.3 \pm 1.0$ & n.a. & n.a. \\
\hline Fast duration before morning fasting urine, $\mathrm{h}$ & $10.1 \pm 1.2$ & $10.2 \pm 1.1$ & n.a. & n.a. \\
\hline Duration of morning fasting urine collection, min & $63 \pm 26$ & $68 \pm 23$ & n.a. & n.a. \\
\hline Solar irradiance, $\mathrm{MJ} / \mathrm{m}^{2}$ per day & n.a. & n.a. & $14.3 \pm 6.7$ & $14.9 \pm 6.8$ \\
\hline
\end{tabular}

^ skewness $<-1$ or $>1$. n.a. $=$ not applicable (not measured or not included in analysis).

\subsection{Kidney Function and Urine $\mathrm{Ca}$}

In the Gubbio study dataset, lower eGFR related to lower $\mathrm{Ca}$ /creatinine ratio in overnight urine and morning fasting urine (Figure 1, upper and central panels). The relationship was similar in first-void 
urine of the Moli-sani study dataset (Figure 1, lower panels). In both datasets, the relationships were more linear with adjustment for age and weight (Figure 1).

\section{Men}
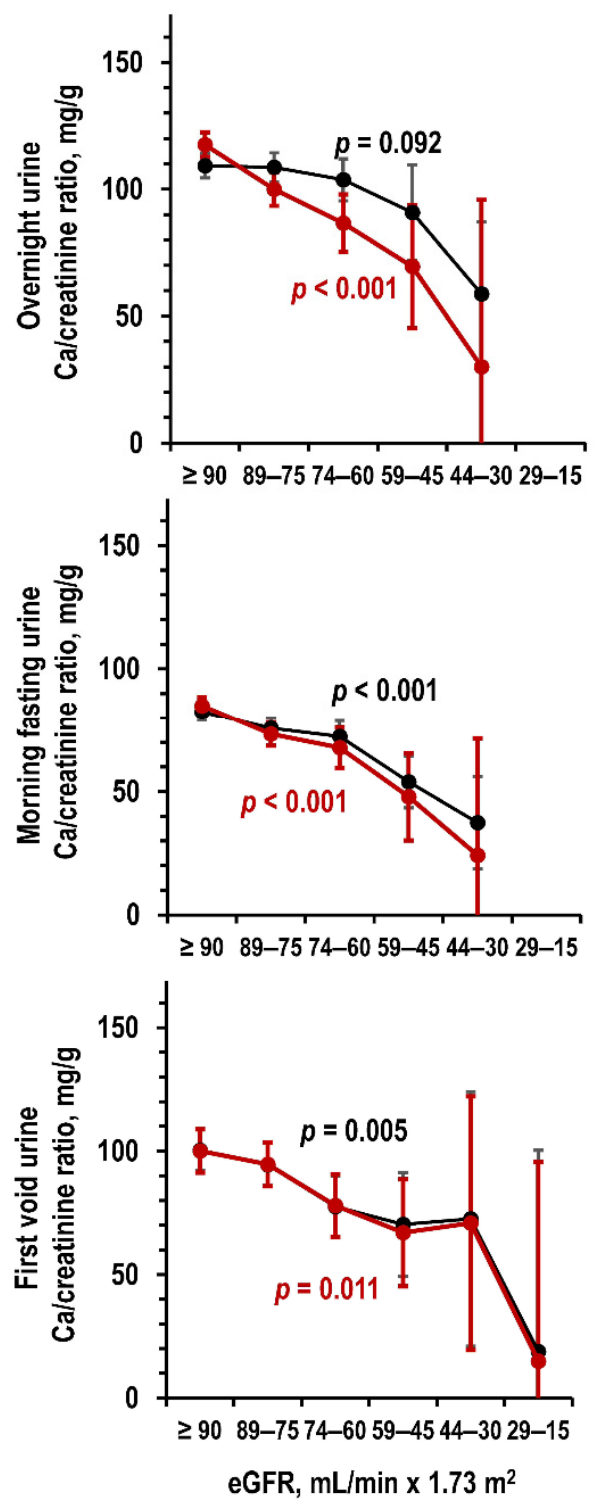

Women
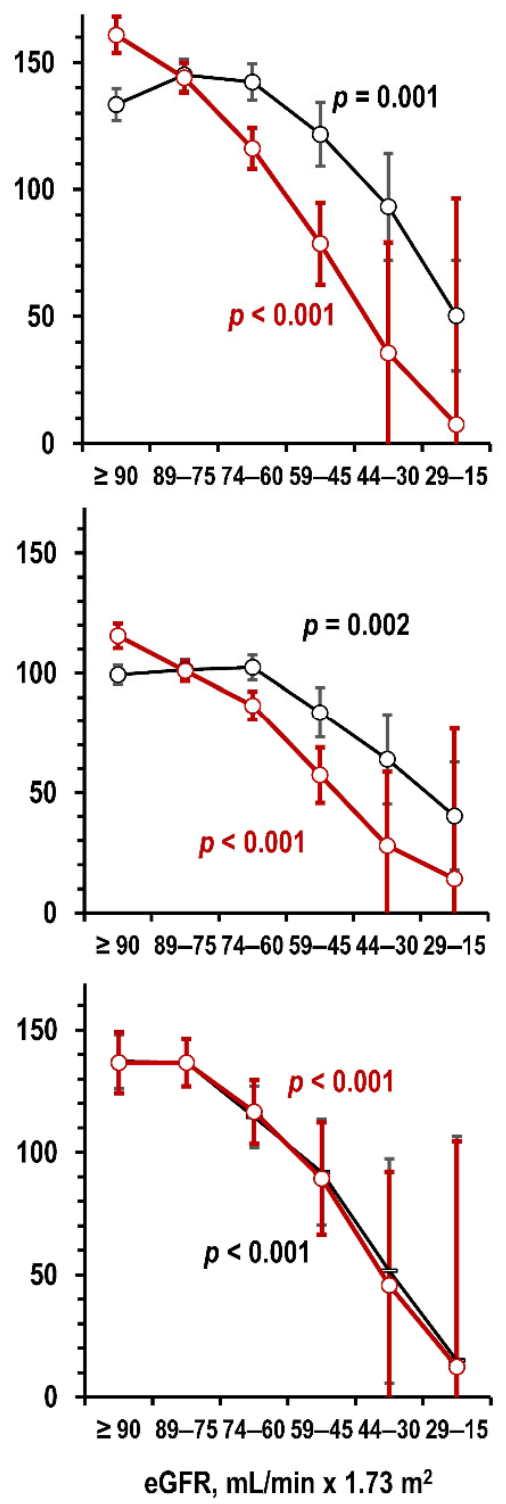

Figure 1. Mean and $95 \% \mathrm{CI}$ of $\mathrm{Ca} /$ creatinine ratio in men and women (left panels and right panels, respectively) by eGFR stratum in overnight urine (upper panels, Gubbio study dataset), in morning fasting urine (central panels, Gubbio study dataset), and in first-void morning urine (lower panels, Moli-sani study dataset) in uni-variate ANOVA and in ANOVA controlled for age and weight (black line and red line, respectively). Number of individuals per eGFR stratum from left to right: Gubbio study dataset, men $=905,451,164,31,4$, and $0-$ women $=680,677,471,109,13$, and 3; Moli-sani study dataset, men $=195,168,88,30,5$, and 2-women $=139,175,107,36,8$, and 2. No individual had $\mathrm{eGFR}<15 \mathrm{~mL} / \mathrm{min} \times 1.73 \mathrm{~m}^{2}$.

Results in the Gubbio study dataset were similar also for overnight urinary Ca excretion rate and estimated $24 \mathrm{~h}$ urinary $\mathrm{Ca}$ (Figure S2), and for overnight urine $\mathrm{Ca} /$ creatinine ratio in the subgroup of 1162 examinees excluded from main analyses (Figure S3).

In linear regression with control for age and weight, a difference in eGFR of $10 \mathrm{~mL} / \mathrm{min} \times 1.73 \mathrm{~m}^{2}$ associated with a difference in overnight urine $\mathrm{Ca} /$ creatinine ratio of $14.0 \mathrm{mg} / \mathrm{g}$ in men and of $17.8 \mathrm{mg} / \mathrm{g}$ in women $(95 \% \mathrm{CI}=11 / 17$ and $15 / 21, p<0.001)$, with a difference in morning fasting urine $\mathrm{Ca} / \mathrm{creatinine}$ 
ratio of $9.3 \mathrm{mg} / \mathrm{g}$ in men and of $11.2 \mathrm{mg} / \mathrm{g}$ in women $(95 \% \mathrm{CI}=7 / 12$ and 9/13, $p<0.001$ ), and with a difference in first-void urine $\mathrm{Ca} / \mathrm{creatinine}$ ratio of $7.7 \mathrm{mg} / \mathrm{g}$ in men and of $9.6 \mathrm{mg} / \mathrm{g}$ in women $(95 \% \mathrm{CI}=4 / 12$ and $5 / 15, p<0.001)$. Results were similar in analyses controlled also for additional variables (Table S4).

\subsection{Kidney Function and Kidney Ca Handling}

In the Moli-sani study dataset, lower eGFR linearly related to lower glomerular filtered load of Ca also after adjustment for age (Figure 2, upper panels). eGFR did not significantly relate to fractional tubular reabsorption and to fractional Ca excretion (Figure 2).
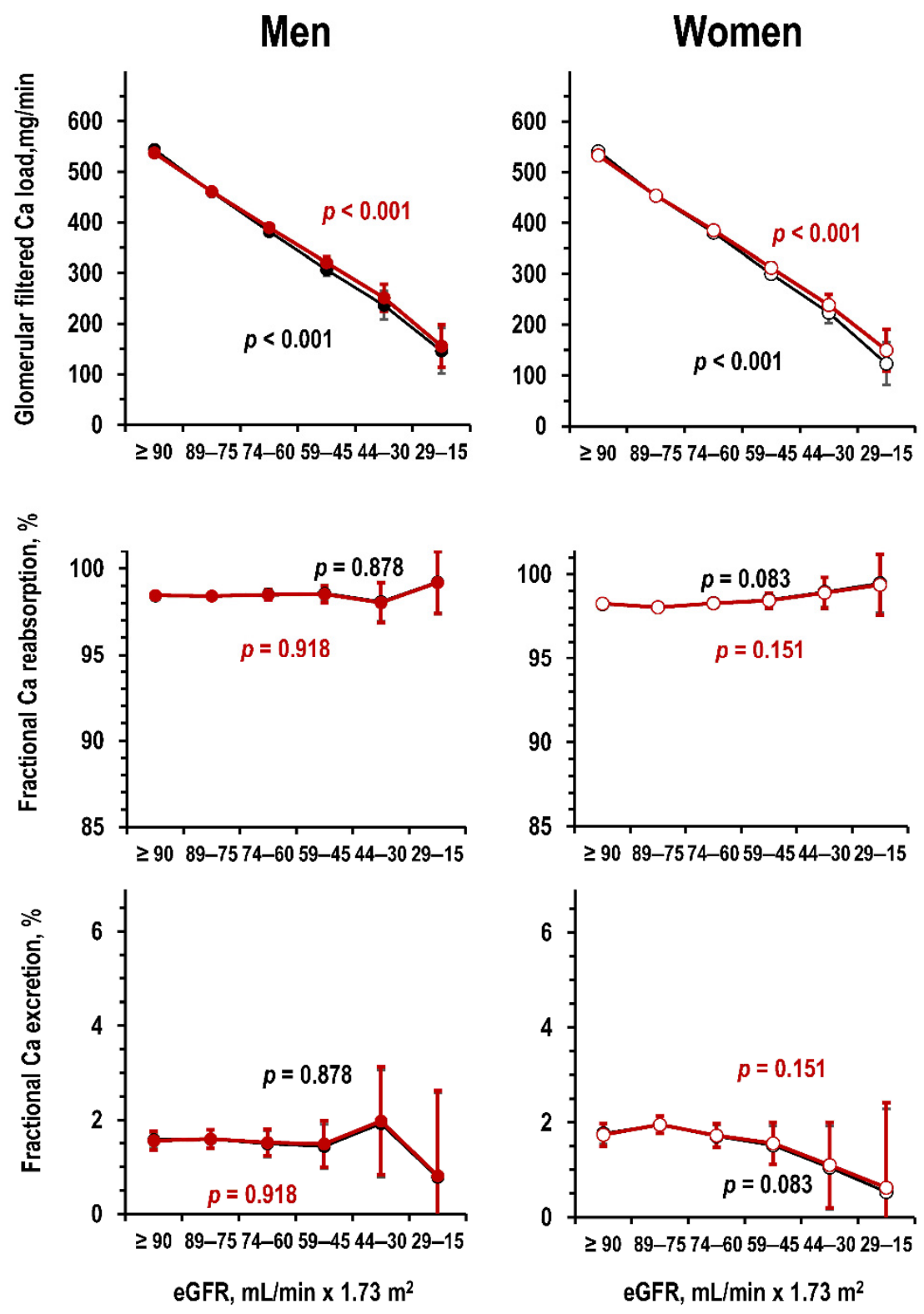

Figure 2. Moli-sani dataset: mean and 95\%CI in men and women (left panels and right panels, respectively) by eGFR stratum of glomerular filtered load of Ca (upper panels), of fractional tubular reabsorption of $\mathrm{Ca}$ (central panels), and of fractional excretion of Ca (lower panels) in uni-variate ANOVA and in ANOVA controlled for age (black line and red line, respectively). Number of individuals per eGFR stratum from left to right: $\operatorname{men}=195,168,88,30,5$, and 2 -women $=139,175,107,36,8$, and 2. No individual had eGFR $<15 \mathrm{~mL} / \mathrm{min} \times 1.73 \mathrm{~m}^{2}$. 


\subsection{Kidney Function and Metabolic Markers of CKD-MBD}

Figures 3 and 4 summarize the results of analyses about the relationships of eGFR with serum metabolic markers of CKD-MBD in the Moli-sani study dataset. Lower eGFR associated with borderline significant trend to higher serum phosphorus in women only and with significant trends to higher PTH and to lower $1,25(\mathrm{OH})_{2} \mathrm{D}$ in both sexes (Figure 3).
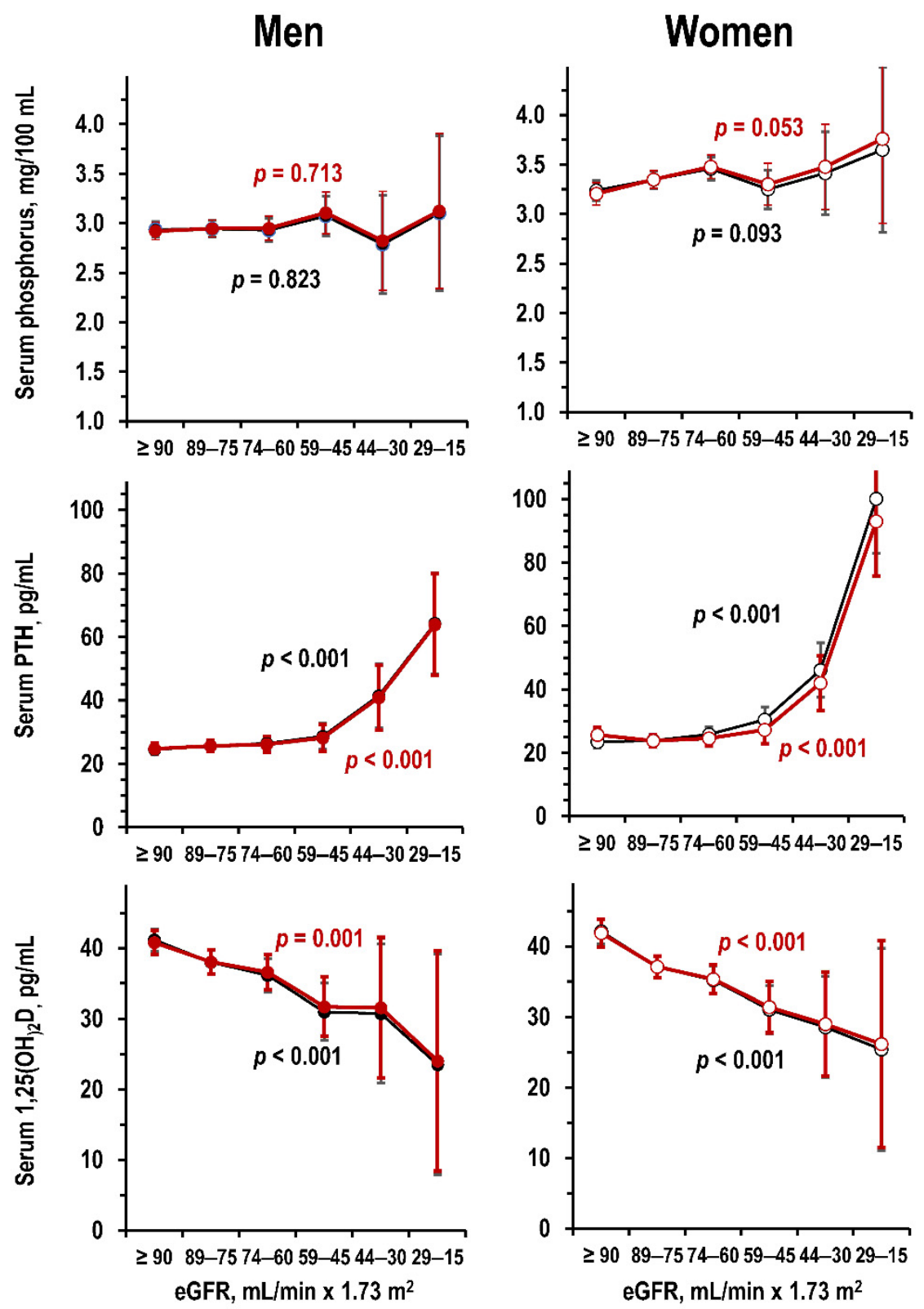

Figure 3. Moli-sani dataset: mean and 95\%CI in men and women (left panels and right panels, respectively) by eGFR stratum of serum phosphorus (upper panels), serum PTH (central panels), and serum $1,25(\mathrm{OH})_{2} \mathrm{D}$ (lower panels) in uni-variate ANOVA and in ANOVA controlled for age (black line and red line, respectively). Number of individuals per eGFR stratum from left to right: men $=195$, $168,88,30,5$, and 2 -women $=139,175,107,36,8$, and 2 . No individual had eGFR $<15 \mathrm{~mL} / \mathrm{min} \times 1.73 \mathrm{~m}^{2}$.

For serum Ca, lower eGFR associated with weak trends to lower total $\mathrm{Ca}$ and higher ultra-filterable $\mathrm{Ca}$ (Figure 4). The contrasting trends between total $\mathrm{Ca}$ and ultrafilterable $\mathrm{Ca}$ were due to the association of lower eGFR with lower serum albumin (Figure S4). Lower eGFR did not associate with lower 25(OH)D (Figure 4). Findings for 25(OH)D were not significant also after control for solar irradiance 
$(p=0.577)$ that was the strongest correlate of $25(\mathrm{OH}) \mathrm{D}$ (standardized regression coefficient, beta $=0.253$, $p<0.001)$.
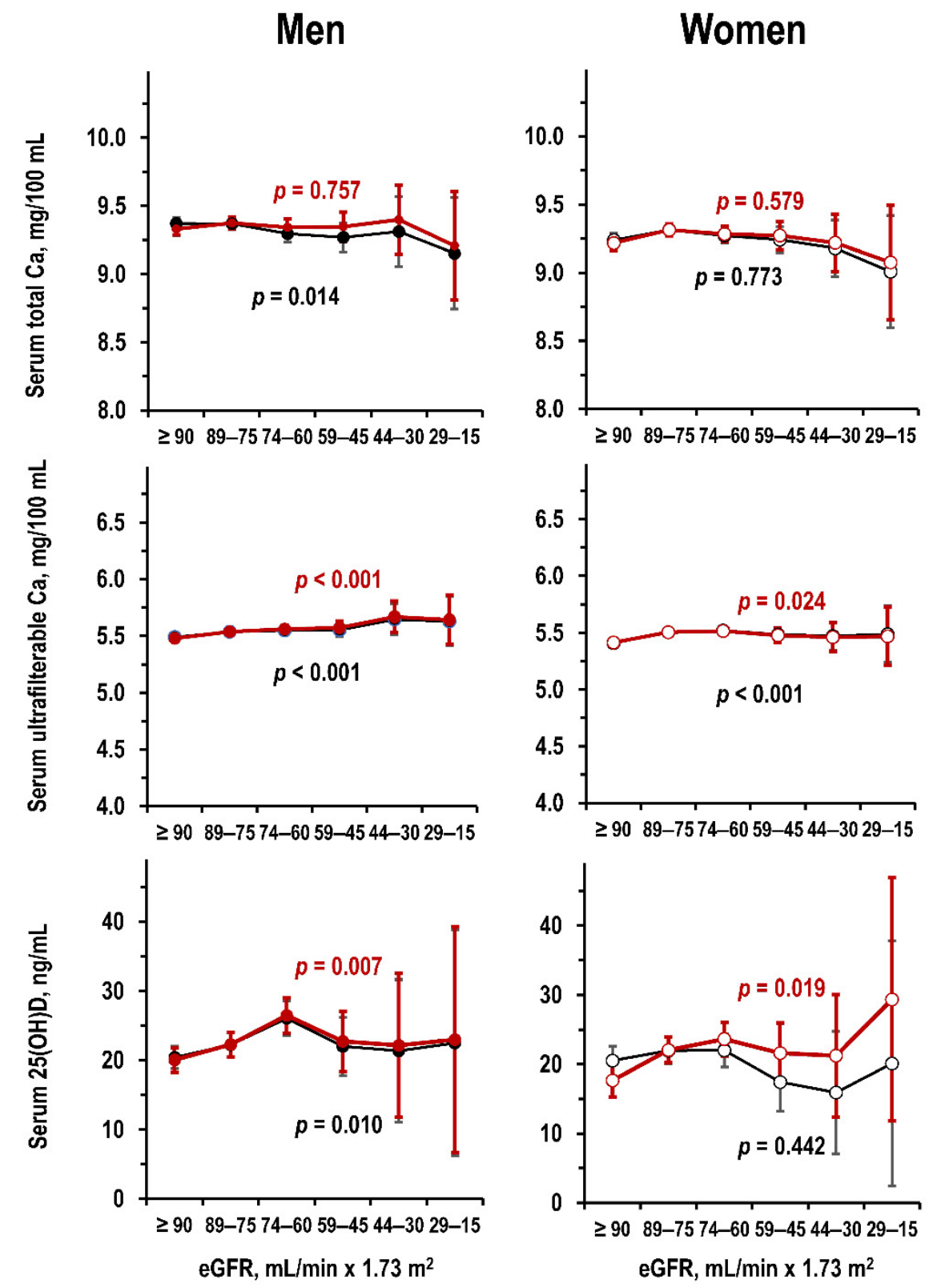

Figure 4. Moli-sani dataset: mean and $95 \% \mathrm{CI}$ in men and women (left panels and right panels, respectively) by eGFR stratum of serum total Ca (upper panels), serum ultrafilterable Ca (central panels), and serum 25(OH)D (lower panels) in uni-variate ANOVA and in ANOVA controlled for age (black line and red line, respectively). Number of individuals per eGFR stratum from left to right: $\operatorname{men}=195,168,88,30,5$, and 2 - women $=139,175,107,36,8$, and 2 . No individual had eGFR $<15 \mathrm{~mL} / \mathrm{min} \times 1.73 \mathrm{~m}^{2}$.

\subsection{Urine Ca and CKD-MBD Metabolic Abnormalities}

In the Moli-sani study data set, men and women had different prevalence of hyperphosphatemia (1.2\% and $7.1 \%, p<0.001)$ but similar prevalence of high serum PTH $(1.2$ and $1.9 \%, p=0.386)$, of low serum $1,25(\mathrm{OH})_{2}(3.1 \%$ and $2.6 \%, p=0.638)$, and of hypocalcemia $(1.0 \%$ and $0.6 \%, p=0.517)$. In uni-variate analyses, reduced kidney function associated not significantly with higher prevalence of high serum $\mathrm{PTH}$, low serum $1,25(\mathrm{OH})_{2} \mathrm{D}$ and hypocalcemia among men, and with higher prevalence of hyperphosphatemia, high serum $\mathrm{PTH}$, and low serum $1,25(\mathrm{OH})_{2} \mathrm{D}$ among women (Table 2). 
Table 2. Moli-sani study dataset: prevalence of hyperphosphatemia, of high serum PTH, of low serum $1,25(\mathrm{OH})_{2} \mathrm{D}$, of hypocalcemia, and of individuals with at least one of the CKD-MBD metabolic abnormalities in the group without reduced kidney function compared to the group with reduced kidney function (eGFR $\geq 90$ and $<90 \mathrm{~mL} / \mathrm{min} \times 1.73 \mathrm{~m}^{2}$, respectively).

\begin{tabular}{|c|c|c|c|c|c|c|}
\hline & \multicolumn{3}{|c|}{ Men } & \multicolumn{3}{|c|}{ Women } \\
\hline & \multicolumn{2}{|c|}{$\begin{array}{c}\text { eGFR } \\
\mathrm{mL} / \mathrm{min} \times 1.73 \mathrm{~m}^{2}\end{array}$} & \multirow{2}{*}{$\begin{array}{c}\text { Odds } \\
\text { Ratio }(95 \% \mathrm{CI})\end{array}$} & \multicolumn{2}{|c|}{$\begin{array}{c}\text { eGFR } \\
\mathrm{mL} / \mathrm{min} \times 1.73 \mathrm{~m}^{2}\end{array}$} & \multirow{2}{*}{$\begin{array}{l}\text { Odds Ratio } \\
(95 \% \mathrm{CI})\end{array}$} \\
\hline & $\geq 90$ & $<90$ & & $\geq 90$ & $<90$ & \\
\hline Number of examinees & 195 & 293 & & 139 & 328 & \\
\hline Hyperphosphatemia, $\%$ & $2.1 \%$ & $0.7 \%$ & $0.33(0.06 / 1.81)$ & $5.8 \%$ & $7.6 \%$ & $1.35(0.59 / 3.07)$ \\
\hline High serum PTH, \% & $0.0 \%$ & $2.0 \%$ & n.c. & $0.7 \%$ & $2.4 \%$ & $3.45(0.43 / 27.85)$ \\
\hline Low serum $1,25(\mathrm{OH})_{2} \mathrm{D}, \%$ & $2.1 \%$ & $3.8 \%$ & $1.86(0.58 / 5.94)$ & $0.0 \%$ & $3.7 \%$ & n.c. \\
\hline Hypocalcemia, \% & $0.5 \%$ & $1.4 \%$ & $2.69(0.30 / 24.2)$ & $0.7 \%$ & $0.6 \%$ & $0.85(0.08 / 9.41)$ \\
\hline Anyone of the above, $\%$ & $4.1 \%$ & $7.2 \%$ & $1.81(0.78 / 4.16)$ & $7.2 \%$ & $13.4 \%$ & $2.00(0.98 / 4.10)$ \\
\hline
\end{tabular}

The relation of urine $\mathrm{Ca} /$ creatinine ratio to prevalence of CKD-MBD metabolic abnormalities was absent in the group without reduced kidney function whereas it was significantly inverse in men and women with reduced kidney function (Figure 5).
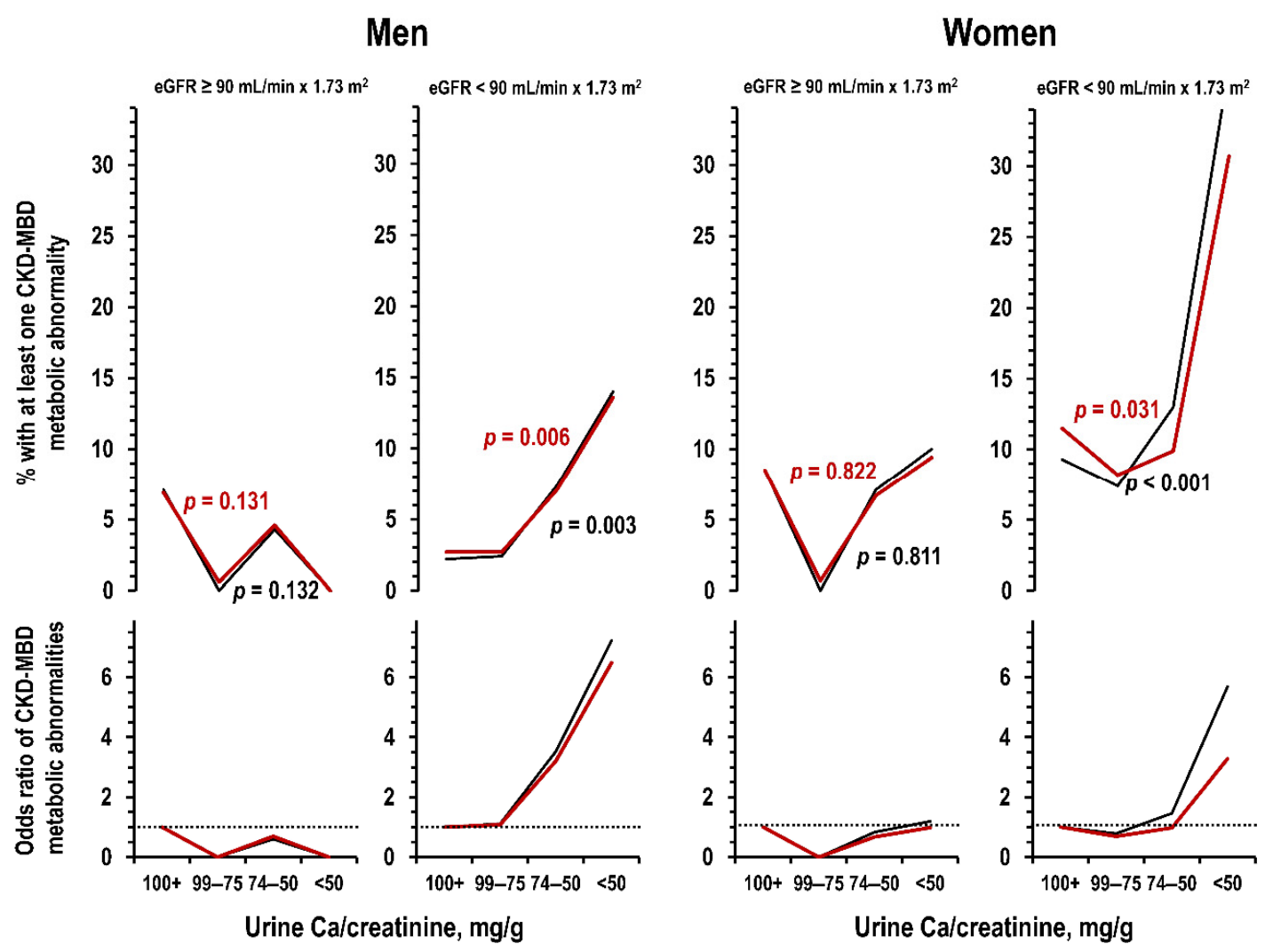

Figure 5. Moli-sani dataset: prevalence (upper panels) and OR (lower panels) of individuals with at least one CKD-MBD metabolic abnormality in men and women (left panels and right panels, respectively) by stratum of urine $\mathrm{Ca}$ /creatinine ratio, in the group without reduced kidney function and in the group with reduced kidney function. Reduced kidney function was defined as eGFR $<90 \mathrm{~mL} / \mathrm{min} \times 1.73 \mathrm{~m}^{2}$. $p$ value are for trend along strata of urine $\mathrm{Ca} / \mathrm{creatinine}$ ratio in univariate analyses and in analyses controlled for age and weight (black line and red line, respectively). Number of individuals per urine $\mathrm{Ca} /$ creatinine stratum from left to right: $\mathrm{men}=176,72,114$, and 126-women $=276,75$, 60, and 56.

When univariate analyses in the group with reduced kidney function were done for single CKD-MBD metabolic abnormality, lower urine $\mathrm{Ca} /$ creatinine ratio related to higher prevalence of low 
$1,25(\mathrm{OH})_{2} \mathrm{D}$ in univariate analysis (OR for $25 \mathrm{mg} / \mathrm{g}$ lower $\mathrm{Ca} / \mathrm{creatinine} \mathrm{ratio} \mathrm{in} \mathrm{men} \mathrm{and} \mathrm{women:}=2.35$ and $1.93,95 \% \mathrm{CI}=1.22 / 4.49$ and $1.27 / 2.93, p<0.01$ ). Findings were not significant for the relation of urine $\mathrm{Ca} /$ creatinine ratio to hyperphosphatemia, high serum $\mathrm{PTH}$, and hypocalcemia (Table S5).

\section{Discussion}

This observational, population-based, cross-sectional analysis reported two main findings. First, there is a continuous, graded, and independent association of lower kidney function with lower urine $\mathrm{Ca}$ and, as expected, with lower glomerular filtered load of $\mathrm{Ca}$, in the absence of alterations in the tubular Ca handling. Second, in individuals with reduced kidney function, the relative hypocalciuria independently associates with increased prevalence of low serum $1,25(\mathrm{OH})_{2} \mathrm{D}$.

The interpretation of observational, cross-sectional data should be cautious. Study results indicated that a reduction in the glomerular filtered Ca load was the sole mechanism responsible for the relative hypocalciuria associated with reduced kidney function, at least over the eGFR range explorable in the two population samples in analysis. This interpretation was coherently supported by different observations: the consistence of results in urine samples under fed condition and after prolonged fast, the independence of findings of dietary markers, Ca supplementation, and duration of overnight fast. The lack of altered tubular $\mathrm{Ca}$ handling in reduced kidney function appeared coherent with the concurrence of conditions capable either to up-regulate and to down-regulate tubular $\mathrm{Ca}$ reabsorption as expected for higher serum PTH and of lower serum $1,25(\mathrm{OH})_{2} \mathrm{D}$ in combination with higher fibroblast growth factor 23 [2,37]. In a finalistic view, the relative hypocalciuria associated with lower kidney function could be interpreted as the alteration through which Ca deficiency was prevented or limited in the presence of reduced serum $1,25(\mathrm{OH})_{2} \mathrm{D}$ secondary to kidney hypofunction.

Regarding metabolic indices of CKD-MBD, study results were coherent with the concept that a chronic reduction in kidney function induces an increase in serum levels of phosphorus and PTH and a decrease in serum $1,25(\mathrm{OH})_{2} \mathrm{D}[1,2]$. For serum $\mathrm{Ca}$, study results indicated associations of lower kidney function with slightly lower total $\mathrm{Ca}$ and slightly higher ultra-filterable Ca due to the association of lower kidney function with slightly lower values of estimated albumin-bound Ca. Last, study results did not indicate alterations of serum $25(\mathrm{OH}) \mathrm{D}$ in reduced kidney function and confirmed the effects of solar irradiance on serum 25(OH)D [22].

Study limitations were the use of the $\mathrm{Ca} /$ creatinine ratio as index of urinary $\mathrm{Ca}$, the lack of 24-h urine collection, the lack of direct measurements of serum ultra-filterable $\mathrm{Ca}$, the lack of standardized Ca intake, the low number of individuals with severe eGFR reduction, and the lack of data for different ethnic groups. The bias due to the use of the $\mathrm{Ca} /$ creatinine ratio was reasonably minor considering that the results in the Gubbio cohort for overnight urine were substantially identical with the use of the urine $\mathrm{Ca} / \mathrm{creatinine}$ ratio and of the timed urine $\mathrm{Ca}$ excretion rate. The use of overnight urine instead of 24-h urine could have caused a bias due a circadian variation in creatinine excretion although overnight urine Ca strongly correlated with same day 24-h urine Ca also with urine Ca factored by urine creatinine [27].

The study had some merits. The population-based design reduced the bias due to low sample size. The use of datasets from temporally and geographically separated epidemiological projects reduced the possibility of local or temporal confounders and proved the reproducibility of the findings. The collection of urine under different conditions proved that findings were independent of the time and the type of urine sample. The use of $\mathrm{Ca} /$ creatinine ratio might have ruled out the bias due to inaccuracies in timing and completeness of urine collections [25]. Lastly, in the Moli-sani data set, the study was based on the most accurate non-invasive index of glomerular filtration [31] and on the reference calibration for serum 25(OH)D measurements [19,20].

Regarding the association of reduced kidney function with relative hypocalciuria, study results were in accordance with those derived from clinical settings where data were collected under different experimental conditions [3,4]. For biochemical markers of CKD-MBD, study results were in accordance with previous evidence reporting consistent associations of reduced kidney function with higher 
serum phosphorus, higher serum $\mathrm{PTH}$, and lower serum $1,25(\mathrm{OH})_{2} \mathrm{D}$ and less consistent association with serum $\mathrm{Ca}[1,36,38]$. Finally, study results were in contrast with the report of an association of kidney function with serum $25(\mathrm{OH}) \mathrm{D}$ [39] and were in accordance with the previously reported lack of association $[36,40,41]$.

In conclusion, this observational, cross-sectional, epidemiological study showed a continuous, graded, and independent relationship between kidney function and urine Ca. The relationship was reproducible in two different population samples, independently of the timing and of the type of the urine collection. The relative hypocalciuria associated with reduced kidney function appeared due to a reduction in the normal glomerular filtered Ca load. It could represent a beneficial adaptation to prevent or to reduce Ca deficiency secondary to the $1,25(\mathrm{OH})_{2} \mathrm{D}$ deficiency associated with reduced kidney function. Data indicated that the assessment of urine $\mathrm{Ca}$ in patients with reduced kidney function could be of use as a supportive evidence of low $1,25(\mathrm{OH})_{2} \mathrm{D}$ and/or for monitoring treatment with calcium or vitamin D.

The main practical implication of the present study is that the assessment of urine Ca could be added to the list of non-invasive analytes used in the diagnosis and monitoring of CKD-MBD [1]. In particular, the assessment of urine Ca could suggest the presence of low $1,25(\mathrm{OH})_{2} \mathrm{D}$ given that, in individuals with reduced kidney function, the prevalence of this metabolic abnormality was progressively higher with reducing the level of urine Ca independently of sex, age, weight, and eGFR. In addition, low urine Ca in reduced kidney function highlights the need of being cautious in the use of Ca supplementation to avoid excessively positive Ca balance in patients with reduced kidney function [42].

Supplementary Materials: The following are available online at http://www.mdpi.com/2077-0383/9/12/4133/s1, Table S1, Gubbio study dataset: examinees included in analyses and examinees excluded from analyses. Table S2, Gubbio study dataset: descriptive statistics by eGFR stratum. Table S3, Moli-sani study dataset: descriptive statistics by eGFR stratum. Table S4, Gubbio study dataset and Moli-sani dataset: additional multivariate linear regression models of urine $\mathrm{Ca}$ /creatinine ratio over eGFR. Table S5, Moli-sani study dataset: relation of urine $\mathrm{Ca} /$ creatinine ratio to prevalence of CKD-MBD metabolic abnormalities in individuals with reduced kidney function. Figure S1, Subgroup analysis: correlation and paired $t$-test for $\mathrm{Ca} /$ creatinine ratio between overnight urine and same day $24 \mathrm{~h}$ urine. Figure S2, Gubbio study dataset: overnight urine Ca excretion rate and estimated $24 \mathrm{~h}$ urinary Ca by sex and eGFR stratum. Figure S3, Gubbio study dataset: Ca/creatinine ratio in overnight urine by sex and eGFR stratum in 1162 examinees excluded from main analyses. Figure S4, Moli-sani study dataset: serum albumin by sex and eGFR stratum.

Author Contributions: All authors contributed to the conception or design of the work; or the acquisition, analysis, or interpretation of data; or have drafted the work or substantively revised it; AND has approved the submitted version; AND agrees to be personally accountable for the author's own contributions and for ensuring that questions related to the accuracy or integrity of any part of the work, even ones in which the author was not personally involved, are appropriately investigated, resolved, and documented in the literature. Individual contributions: research idea and study design, M.C. and L.I.; data acquisition, F.G., P.C., G.I., S.C., A.D.C. (Amalia De Curtis), and A.D.C. (Augusto Di Castelnuovo); data interpretation, M.C.; statistical analysis: G.B.; supervision or mentorship: M.C. and L.I. All authors have read and agreed to the published version of the manuscript.

Funding: The Gubbio study received economic support in the past by Merck, Sharp \& Dohme-Italy, by the US National Heart, Lung, and Blood Institute (Grant R01HL-40397-02), and by Ministero Italiano di Università e Ricerca (Grant \# 068034). The study was realized in collaboration with Gubbio Hospital (PG, Italy), Federico II University of Naples (NA, Italy), University of Milan (MI, Italy), Northwestern University of Chicago (IL, USA), Istituto Superiore di Sanità (Rome, Italy). The study in the Moli-sani sub-cohort was realized also thanks to a grant from the Agenzia Spaziale Italiana (Rome, Italy-ASI contract No 2013-093-R.0). The enrolment phase of the Moli-sani study was supported by research grants from the Pfizer Foundation (Rome, Italy), the Italian Ministry of University and Research (Rome, Italy), from the Programma Triennale di Ricerca, Decreto 1588, and from the Instrumentation Laboratory (Milan, Italy).

Acknowledgments: The Gubbio study was made possible thanks to the enthusiasm of the people of the town of Gubbio and to the support of its municipal and health authorities and community leaders. The study is currently guided by 'Centro Studi Epidemiologici di Gubbio' Gubbio (PG, Italy). The Moli-sani research group thanks the Associazione Cuore Sano Onlus (Campobasso, Italy) for its support.

Conflicts of Interest: The authors declare no conflict of interest. 


\section{References}

1. Kidney Disease: Improving Global Outcomes (KDIGO) CKD-MBD Work Group. KDIGO clinical practice guideline for the diagnosis, evaluation, prevention, and treatment of chronic kidney disease-mineral and bone disorder (CKD-BD). Kidney Int. Suppl. 2009, 113, S1-S130. [CrossRef]

2. Kestenbaum, B.; Drüeke, T.B. Disorders of calcium, phosphate, and magnesium metabolism. In Comprehensive Clinical Nephrology, 4th ed.; Floege, J., Johnson, R., Feehally, J., Eds.; Elsevier Saunders: St. Louis, MO, USA, 2010; Volume 1, pp. 130-148.

3. Marco Mayayo, M.P.; Martínez, I.; Rué i Monné, M.; Borràs, M.; Martín Ramos, M.L.; Sarró, F.; Valdivielso Revilla, J.M.; Fernández i Giráldez, E. Mineral metabolism parameters throughout chronic kidney disease stages 1-5-Achievement of K/DOQI target ranges. Nephrol. Dial. Transplant. 2007, 22, 1171-1176. [CrossRef]

4. Ramalho, J.; Petrillo, E.M.; Takeichi, A.P.M.; Moyses, R.M.A.; Titan, S.M. Calcitriol and FGF-23, but neither PTH nor sclerostin, are associated with calciuria in CKD. Int. Urol. Nephrol. 2019, 51, 1823-1829. [CrossRef] [PubMed]

5. Kadlec, A.O.; Greco, K.A.; Fridirici, Z.C.; Gerber, D.; Turk, T.M.T. Effect of renal function on urinary mineral excretion and stone composition. Urology 2011, 78, 744-747. [CrossRef] [PubMed]

6. Gershman, B.; Sheth, S.; Dretler, S.P.; Herrick, B.; Lang, K.; Pais, V.M., Jr.; Eisner, B.H. Relationship between glomerular filtration rate and 24-h urine composition in patients with nephrolithiasis. Urology 2012, 80, 38-42. [CrossRef] [PubMed]

7. Lemann, J., Jr.; Worcester, E.M.; Gray, R.W. Hypercalciuria and stones. Am. J. Kidney Dis. 1991, 17, 386-391. [CrossRef]

8. Pak, C.Y.; Kaplan, R.; Bone, H.; Townsend, J.; Waters, O. A simple test for the diagnosis of absorptive, resorptive and renal hypercalciurias. N. Engl. J. Med. 1975, 292, 497-500. [CrossRef]

9. Cirillo, M.; Terradura-Vagnarelli, O.; Mancini, M.; Menotti, A.; Zanchetti, A.; Laurenzi, M. Cohort profile: The Gubbio population study. Int. J. Epidemiol. 2014, 43, 713-720. [CrossRef]

10. Cirillo, M.; Zingone, F.; Lombardi, C.; Cavallo, P.; Zanchetti, A.; Bilancio, G. Population-based dose-response curve of glomerular filtration rate to dietary protein intake. Nephrol. Dial. Transplant. 2015, 30, 1156-1162. [CrossRef] [PubMed]

11. Cirillo, M.; Ciacci, C.; De Santo, N.G. Age, renal tubular phosphate reabsorption, and serum phosphate levels in adults. N. Engl. J. Med. 2008, 359, 864-866. [CrossRef] [PubMed]

12. Myers, G.L.; Miller, W.G.; Coresh, J.; Fleming, J.; Greenberg, N.; Greene, T.; Hostetter, T.; Levey, A.S.; Panteghini, M.; Welch, M.; et al. Recommendations for improving serum creatinine measurement: A report from the Laboratory Working Group of the National Kidney Disease Education Program. Clin. Chem. 2006, 52, 5-18. [CrossRef] [PubMed]

13. Di Castelnuovo, A.; Costanzo, S.; Persichillo, M.; Olivieri, M.; De Curtis, A.; Zito, F.; Donati, M.B.; De Gaetano, G.; Iacoviello, L. Distribution of short and lifetime risks for cardiovascular disease in Italians. Eur. J. Prev. Cardiol. 2012, 19, 723-730. [CrossRef] [PubMed]

14. Iacoviello, L.; De Curtis, A.; Donati, M.B.; de Gaetano, G. Biobanks for cardiovascular epidemiology and prevention. Future Cardiol. 2014, 10, 243-254. [CrossRef] [PubMed]

15. Zeller, T.; Hughes, M.; Tuovinen, T.; Schillert, A.; Conrads-Frank, A.; Den Ruijter, H.; Schnabel, R.B.; Kee, F.; Salomaa, V.; Siebert, U.; et al. BiomarCaRE: Rationale and design of the European BiomarCaRE project including 300,000 participants from 13 European countries. Eur. J. Epidemiol. 2014, 29, 777-790. [CrossRef] [PubMed]

16. Cirillo, M.; Bilancio, G.; Guarino, E.; Cavallo, P.; Lombardi, C.; Costanzo, S.; De Curtis, A.; Di Castelnuovo, A.; Iacoviello, L. Vitamin D Status and indices of mineral homeostasis in the population: Differences between 25-hydroxyvitamin D and 1,25-dihydroxyvitamin D. Nutrients 2019, 11, 1777. [CrossRef]

17. Pauli, D.; Seyfarth, M.; Dibbelt, L. The Abbott Architect c8000: Analytical performance and productivity characteristics of a new analyzer applied to general chemistry testing. Clin. Lab. 2005, 51, 31-41.

18. Valcour, A.; Zierold, C.; Podgorski, A.L.; Olson, G.T.; Wall, J.V.; DeLuca, H.F.; Bonelli, F. A novel, fully-automated, chemiluminescent assay for the detection of 1,25-dihydroxyvitamin D in biological samples. J. Steroid. Biochem. Mol. Biol. 2016, 164, 120-126. [CrossRef]

19. De la Hunty, A.; Wallace, A.M.; Gibson, S.; Viljakainen, H.; Lamberg-Allardt, C.; Ashwell, M. UK Food Standards Agency Workshop Consensus Report: The choice of method for measuring 25-hydroxyvitamin D to estimate vitamin D status for the UK National Diet and Nutrition Survey. Br. J. Nutr. 2010, 104, 612-619. [CrossRef] 
20. Phinney, K.W.; Bedner, M.; Tai, S.S.; Vamathevan, V.V.; Sander, L.C.; Sharpless, K.E.; Wise, S.A.; Yen, J.H.; Schleicher, R.L.; Chaudhary-Webb, M.; et al. Development and certification of a standard reference material for vitamin D metabolites in human serum. Anal. Chem. 2012, 84, 956-962. [CrossRef]

21. ENEA-Italian National Agency for New Technologies, Energy and Sustainable Economic Development. Italian Atlas of Solar Irradiation. Available online: www.solaritaly.enea.it (accessed on 18 March 2018).

22. Engelsen, O. The relationship between ultraviolet radiation exposure and vitamin D status. Nutrients 2010, 2, 482-495. [CrossRef]

23. Levey, A.S.; Stevens, L.A.; Schmid, C.H.; Zhang, Y.; Castro, A.F., III; Feldman, H.I.; Kusek, J.W.; Eggers, P.; Van Lente, F.; Greene, T.; et al. A new equation to estimate glomerular filtration rate. Ann. Intern. Med. 2009, 150, 604-612. [CrossRef] [PubMed]

24. Gökçe, Ç.; Gökçe, Ö.; Baydinç, C.; Îlhan, N.; Alaşehirli, E.; Özküçük, F.; Taşçi, M.; Atikeler, M.K.; Çelebi, H.; Arslan, N. Use of random urine samples to estimate total urinary calcium and phosphate excretion. Arch. Intern. Med. 1991, 151, 1587-1588. [CrossRef] [PubMed]

25. John, K.A.; Cogswell, M.E.; Campbell, N.R.; Nowson, C.A.; Legetic, B.; Hennis, A.J.; Patel, S.M. Accuracy and usefulness of select methods for assessing complete collection of 24-h urine: A systematic review. J. Clin. Hypertens. 2016, 18, 456-467. [CrossRef]

26. He, J.; Klag, M.J.; Whelton, P.K.; Chen, J.Y.; Mo, J.P.; Qian, M.C.; Coresh, J.; Mo, P.S.; He, G.Q. Agreement between overnight and 24-h urinary cation excretions in southern Chinese men. Am. J. Epidemiol. 1993, 137, 1212-1220. [CrossRef] [PubMed]

27. Cirillo, M.; Stellato, D.; Panarelli, P.; Laurenzi, M.; De Santo, N.G. Cross-sectional and prospective data on urinary calcium and urinary stone disease. Kidney Int. 2003, 63, 2200-2206. [CrossRef]

28. Ix, J.H.; Wassel, C.L.; Stevens, L.A.; Beck, G.J.; Froissart, M.; Navis, G.; Rodby, R.; Torres, V.E.; Zhang, Y.L.; Greene, T.; et al. Equations to estimate creatinine excretion rate: The CKD Epidemiology Collaboration. Clin. J. Am. Soc. Nephrol. 2011, 6, 184-191. [CrossRef]

29. Cirillo, M.; Cavallo, P.; Bilancio, G.; Lombardi, C.; Terradura Vagnarelli, O.; Laurenzi, M. Low protein intake in the population: Low risk of kidney function decline but high risk of mortality. J. Ren. Nutr. 2018, 28, 235-244. [CrossRef]

30. Charles, P. Calcium absorption and calcium bioavailability. J. Intern. Med. 1992, 231, 161-168. [CrossRef]

31. Inker, L.A.; Schmid, C.H.; Tighiouart, H.; Eckfeldt, J.H.; Feldman, H.I.; Greene, T.; Kusek, J.W.; Manzi, J.; Van Lente, F.; Zhang, Y.L.; et al. Estimating glomerular filtration rate from serum creatinine and cystatin C. N. Engl. J. Med. 2012, 367, 20-29. [CrossRef]

32. Cirillo, M.; Lombardi, C.; Luciano, M.G.; Bilancio, G.; Anastasio, P.; De Santo, N.G. Estimation of GFR: A comparison of new and established equations. Am. J. Kidney Dis. 2010, 56, 802-804. [CrossRef]

33. Besarab, A.; Caro, J.F. Increased absolute calcium binding to albumin in hypoalbuminaemia. J. Clin. Pathol. 1981, 34, 1368-1374. [CrossRef] [PubMed]

34. Phelps, K.R.; Lieberman, R.L. Fractional excretion and reabsorption in chronic kidney disease. Clin. Nephrol. 2012, 77, 484-490. [CrossRef]

35. Mayo Clinic Laboratories. Test Catalog. Available online: https:/www.mayocliniclabs.com/test-catalog/ (accessed on 20 June 2019).

36. National Kidney Foundation. K/DOQI Clinical practice guidelines for chronic kidney disease: Evaluation, classification and stratification. Am. J. Kidney Dis. 2002, 39 (Suppl. S1), S1-S266.

37. Musgrove, J.; Wolf, M. Regulation and effects of FGF23 in chronic kidney disease. Annu. Rev. Physiol. 2020, 82, 365-390. [CrossRef]

38. Inker, L.A.; Grams, M.E.; Levey, A.S.; Coresh, J.; Cirillo, M.; Collins, J.F.; Gansevoort, R.T.; Gutierrez, O.M.; Hamano, T.; Heine, G.H.; et al. Relationship of estimated GFR and albuminuria to concurrent laboratory abnormalities: An individual participant data meta-analysis in a global consortium. Am. J. Kidney Dis. 2019, 73, 206-217. [CrossRef] [PubMed]

39. Levin, A.; Bakris, G.L.; Molitch, M.; Smulders, M.; Tian, J.; Williams, L.A.; Andress, D.L. Prevalence of abnormal serum vitamin D, PTH, calcium, and phosphorus in patients with chronic kidney disease: Results of the study to evaluate early kidney disease. Kidney Int. 2007, 71, 31-38. [CrossRef]

40. John, A.S.; Thomas, M.B.; Davies, C.P.; Mullan, B.; Dick, I.; Hutchison, B.; van der Schaff, A.; Prince, R.L. Determinants of intact parathyroid hormone and free 1,25-dihydroxyvitamin D levels in mild and moderate renal failure. Nephron 1992, 61, 422-427. [CrossRef] 
41. Ishimura, E.; Nishizawa, Y.; Inaba, M.; Matsumoto, N.; Emoto, M.; Kawagishi, T.; Shoji, S.; Okuno, S.; Kim, M.; Miki, T.; et al. Serum levels of 1,25-dihydroxyvitamin D, 24,25-dihydroxyvitamin D, and 25-hydroxyvitamin $\mathrm{D}$ in nondialyzed patients with chronic renal failure. Kidney Int. 1999, 55, 1019-1027. [CrossRef]

42. Isakova, T.; Gutierrez, O.; Shah, A.; Castaldo, L.; Holmes, J.; Lee, H.; Wolf, M. Postprandial mineral metabolism and secondary hyperparathyroidism in early CKD. J. Am. Soc. Nephrol. 2008, 19, 615-623. [CrossRef]

Publisher's Note: MDPI stays neutral with regard to jurisdictional claims in published maps and institutional affiliations.

(C) 2020 by the authors. Licensee MDPI, Basel, Switzerland. This article is an open access article distributed under the terms and conditions of the Creative Commons Attribution (CC BY) license (http://creativecommons.org/licenses/by/4.0/). 